\title{
Class absenteeism: reasons for non-attendance and the effect on academic performance
}

\author{
Astrid Schmulian $^{\mathrm{a}}$ and Stephen Coetzee ${ }^{\mathrm{a}}$ \\ ${ }^{a}$ Department of Accounting, Faculty of Economic and Management Sciences, University of Pretoria, Pretoria, \\ 0002, South Africa. astrid.schmulian@up.ac.za
}

\begin{abstract}
Purpose - Other business education literature, particularly in the field of economics, has developed theories in respect of the reasons for non-attendance of lectures and the positive correlation between class attendance and academic performance. The aim of this study was to determine the generalizability of these theories to a large accounting class in South Africa. Design/methodology - This paper is a differentiated replication of the study by Paisey and Paisey (2004), who provided initial evidence of the generalizability of these theories to a small accounting class in Scotland, employing a research questionnaire and the analysis of quantitative and qualitative data.
\end{abstract}

Findings - The reasons given for the non-attendance of lectures generally correspond with those previously reported. Certain differences as result of specific country or economic factors where identified. This study found a significant positive correlation between class attendance and academic performance; however the correlation is low and not very meaningful. Further analysis reveals some difference between language groups suggesting that culture and ethnicity may have an effect on the relationship between class attendance and academic performance.

Originality/value - This paper raises questions as to the generalizability, to an accounting education context, of the theories developed in other business-related courses, in respect of the reasons for non-attendance of lectures and the correlation between class attendance and academic performance. Further this paper raises questions as to the generalizability, to an accounting education context, of the results across cultural and ethnic backgrounds.

Keywords Absenteeism; accounting; attendance; academic performance; survey; South Africa

\section{Paper type Research Paper}




\section{Introduction}

Accounting lectures at tertiary level in South Africa tend to focus on the application of accounting rules in various fictitious single answer scenarios (Botha, 2001; UP, 2009) This focus is largely driven by the nature of the South African professional qualifying examinations which assess students' competence based on such scenarios (Botha, 2001; SAICA, 2005; van der Schyf, 2008). Students who miss lectures lose the benefit of having this application explained and demonstrated to them. In addition, these absentee students forfeit the benefit: of the auditory and visual supplementation of the textbook (Sleigh \& Ritzer, 2001); the opportunity to learn from questions asked by other students during lectures and the resultant explanation provided by the lecturer (Sleigh \& Ritzer, 2001); the guidance provided in the critical thought process through the line of questioning followed by a lecturer; and the ability to generate class notes as an additional source of information (Marburger, 2001).

The benefits associated with class attendance have lead researchers to hypothesis that class attendance should positively correlate with academic performance (Durden \& Ellis, 1995; Devadoss \& Foltz, 1996; Rodgers, 2001; Marburger, 2001; Rodgers \& Rodgers, 2003; Paisey \& Paisey, 2004; Gump, 2005; Sauers et al., 2005; Woodfield et al., 2006; Massingham \& Herrington, 2006; Halpern, 2007; Chen \& Lin, 2008; Newman-Ford et al., 2008; Horn \& Jansen, 2009; Credé et al., 2010). These researchers have generally confirmed this correlation - although cautioning that the link could be no more than a casual one as students who attend lectures may already be more predisposed to academic achievement (Romer, 1993; Devadoss \& Foltz, 1996; Marburger, 2001; Rodgers, 2001; Paisey \& Paisey, 2004; Gendron \& Pieper, 2005; Halpern, 2007) and may exhibit greater levels of motivation (Longhurst, 1999; Massingham \& Herrington, 2006; Moore et al., 2008).

Despite the evidence that there may be a positive relationship between attendance and academic performance, some students continue to be absent from lectures. Researchers have identified several possible reasons for this absence. These reasons vary from the more 'valid' reasons, such as illness and part-time work (Longhurst, 1999; Paisey \& Paisey, 2004; Woodfield et al., 2006; Massingham \& Herrington, 2006) to less 'valid' reasons, such as sleeping late and engaging in various forms of merrymaking (Longhurst, 1999; Paisey \& Paisey, 2004; Moore et al., 2008).

Much of the research at the university level investigating the reasons for nonattendance and the possible correlation between student attendance and academic performance has been performed in various business and economics subjects other than 
accounting. Researchers applying the Myers-Briggs Type Indicator have concluded that accounting students' personality types and learning styles differ from students in other disciplines (Booth \& Winzar, 1993; Wolk \& Nikolai, 1997; Briggs et al., 2007). Further it has been suggested that accounting students differ from other students in terms of achievement, attitude, goal-orientation, independence, self-discipline etc. (Giacomino \& Akers, 1998; Ridener, 1999). Accordingly, given these differing characteristics the generalizability, to an accounting context, of the theories developed outside of accounting may be limited (Ylijoki, 2000). Limited research considering class attendance has been conducted in an accounting context. Paisey and Paisey (2004) conducted an exploratory study in this regard and their results provided initial confirmation of the generalizability of the theories developed in the broader body of literature to an accounting context (see Table I for a description of this context).

The results reported by Paisey and Paisey (2004) are however limited to a small accounting class of 81 students in Scotland. The generalizability of the theories has therefore yet to be established in a larger accounting class in another country. It is submitted that the background of the students who study at a South African university may differ from that of students who study at a Scottish university. Non-attendance at a South African university could potentially be influenced by factors which may not be present in Scotland, such as a non-existent or very poor public transport system, language barriers and vastly different levels of quality and pedagogical styles within school education systems as result of previous historical and political influences. Further preliminary research by McChlery and Visser (2009) has hinted at possible learning style differences between accounting students in the United Kingdom and South Africa. Unfortunately the research instrument used by these authors exhibited 'statistical weakness in regard to several dimensions' (McChlery \& Visser, 2009) and precisely what the differences in learning style preferences are is difficult to reliably ascertain. Suffice to say though, that the broader body of literature on learning style differences has identified a latent association between students' levels of individualism and their preference to learn by doing or watching (Sugahara and Boland, 2009). Accordingly any difference between the Scottish and South African students' learning style preferences may impact on their preference to 'watch' (i.e. attend lectures or not). 
Table I: Comparison of the context of this study to that of Paisey and Paisey (2004)

\section{Paisey \& Paisey (2004)}

Cohort of students: third-year students for a BA or BA (Hons) Accounting degree accredited by the main UK accounting bodies.

Classes: Lectures and seminars.

Assessment: Independent research coursework and a written assessment.

Staff: Three educators involved.

Population: 81 students.

Economic environment: Developed.

Course language: English.

\section{This study}

Cohort of students: second-year students studying for a B Com (Accounting Sciences) degree accredited by the South African Institute of Chartered Accountants. Classes: Lectures.

Assessment: Four written assessments.

Staff: Two educators involved.

Population: 442 students.

Economic environment: Developing. Course language: English and Afrikaans. ${ }^{2}$

The purpose of this study is to expand on that of Paisey and Paisey (2004) through performing a differentiated replication ${ }^{1}$ of their study to determine the generalizability of the theories established in the literature to a larger accounting class in South Africa. In particular this study aims to determine, within the context of a larger accounting class in South Africa:

- the reasons for non-attendance of lectures, and

- whether there is any correlation between class attendance and academic performance.

The findings of this paper hold importance for both lecturers and students in accounting education programmes in view of the declining attendance rates that have been observed in a variety of disciplines across several universities (Rodgers \& Rodgers, 2003; St. Clair, 1999). Lecturers may consider the appropriateness of their style of pedagogy given the outcomes of the study and whether they are adding value in the classroom. Students, and other parties with a vested interest in a student's academic performance, namely parents; grantors of financial support; the university and the accounting profession, may also be interested in indicators demonstrating the possible value being added by a student's class attendance.

The following section of the paper provides the background to the study after which the research design and method is documented and, finally the results and conclusions of this study are presented.

\section{Background}

The University of Pretoria is one of 13 residential universities in South Africa accredited by the South African Institute of Chartered Accountants (SAICA) to educate chartered accountants. The route to qualifying as a chartered accountant in South Africa is illustrated in illustration 1. Essentially this route involves completing four years of academic study at an

\footnotetext{
${ }^{1}$ Lindsay and Ehrenberg (1993) define a differentiated replication as deliberate or known variation on a major aspect of a study with the aim of extending the known range of conditions for which the result may hold true.
} 
accredited university. Following this education programme a period of three years of training is undertaken. During this time spent in training, the professional qualifying examinations, set and administered by the professional body, are written.

Illustration I: Qualification as a chartered accountant in South Africa

Three year full-time B Com accounting degree, or equivalent, at a tertiary education institution.

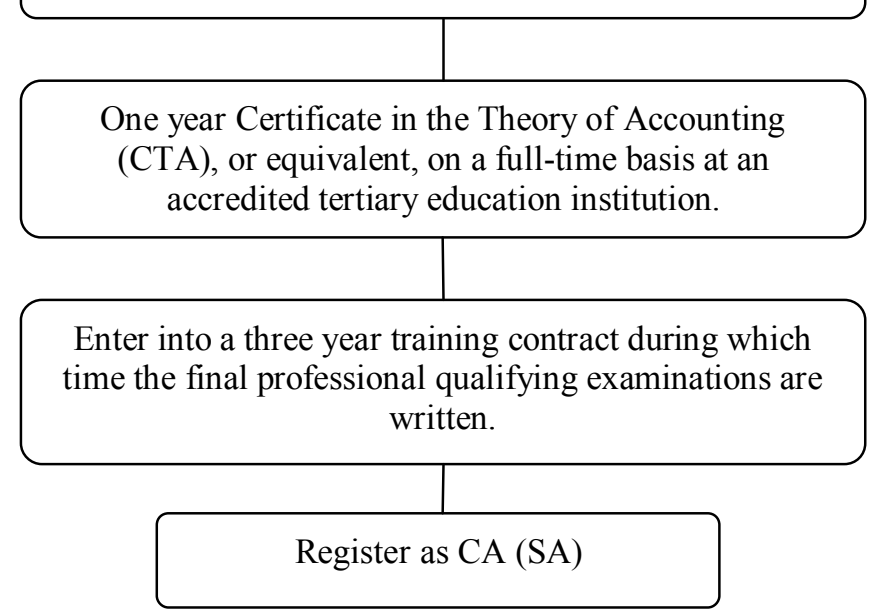

One of the major subjects for which students must enrol, when studying towards professional accounting qualification, is financial accounting (SAICA, 2005). Following a bookkeeping course presented in the first year, the second year students are introduced to International Financial Reporting Standards (IFRS). IFRS forms the focus of the students' remaining years of study. As the University of Pretoria is a full-time study facility, lectures are the primary medium of instruction, supported by a textbook. The style of pedagogy adopted in the lectures is very teacher-centred. The IFRS rules are presented in class and their practical application in typical rule-based, written assessment questions, illustrated. Additional examples and self-study questions and solutions are handed out during class. Students who miss a class can obtain these hand outs from the lecturer. In addition, assessments written in previous years are made available to the students for additional practice. In accordance with departmental policy, copies of the lecturers' notes for the lectures are not made available to the students (UP, 2009). 
The course is presented to two groups of approximately 200 students each. One group represents the English students and the other the Afrikaans ${ }^{2}$ students and each group has its own lecturer. The Afrikaans group consists primarily (99,5\%) of White students, while the English group has a significant majority (62\%) of African students. Although the material presented and available to the students is in English and Afrikaans, the lecturers pay specific attention to ensuring that the content of the lectures delivered to both groups is as near identical as possible. The lecturers both follow the prescribed syllabus, use the same examples in class and compare their lecture notes prior to each lecture to ensure the greatest measure of uniformity possible in the presentations made to both language groups. However, it must be conceded that each lecturer does have an individual style, which could have an influence on the students.

\section{Method}

\section{Reasons for non-attendance of lectures}

In determining the reasons for non-attendance this study replicated the questionnaire developed by Paisey and Paisey (2004). The questionnaire incorporated some open-ended questions (as highlighted in the discussion below). These were analysed using inductive logic. The remainder of data collected from the questionnaire was of a quantitative nature. The questionnaire was issued at the completion of the module to all students who were enrolled for this accounting course and not only to those students who were enrolled for the first time. Those students who had not passed the module on a previous attempt could possibly provide insightful reasons for their non-attendance, which could differ from that of the first-time students. The final number of students included in the population for the distribution of the questionnaire was 442 . A total of 415 usable anonymous responses were received. This response rate is high, but it has to be taken into account that some students did not complete the questionnaire and that these students could have been regular absentees and could possibly have had additional comments and/or responses to the questionnaire.

The demographic profile of the respondent group is illustrated in table II. The majority of students $(84,3 \%)$ were between 19 and 21 years of age. The gender split for the respondent group is even, with $50,1 \%$ of the students being male. Most of the students $(63,3 \%)$ indicated that their parents finance their studies, while a further $17,2 \%$ have student

\footnotetext{
${ }^{2}$ Afrikaans is a West Germanic language, spoken natively in South Africa. With approximately 6 million native speakers in South Africa, or 13.3 percent of the population, it is the third most spoken mother tongue in the country (de Swaan, 2001).
} 
loans. Many of the students (48,7\%) live with their parents while a further $22,9 \%$ indicated that they lived in a student hostel and 19,8\% lived in their own accommodation (for example, a flat).

Table II: Student demographics

\begin{tabular}{lccc}
\hline & Male & Female & Total \\
\hline Afrikaans & 109 & 88 & 197 \\
English & 99 & 119 & 218 \\
\cline { 2 - 4 } Total & 208 & 207 & 415 \\
0 & 50,1 & 49,9 & 100
\end{tabular}

\begin{tabular}{lcccccccc} 
& \multicolumn{9}{c}{ Age } & & & \\
& 18 & 19 & 20 & 21 & 22 & Other & No response & Total \\
\hline Afrikaans & - & 20 & 97 & 45 & 22 & 13 & - & 197 \\
English & 3 & 47 & 94 & 46 & 21 & 6 & 1 & 218 \\
Number & 3 & 67 & 191 & 91 & 43 & 19 & 1 & 415 \\
$\%$ & 0,7 & 16,2 & 46,1 & 22,0 & 10,4 & 4,6 & - & 100 \\
\hline
\end{tabular}

\begin{tabular}{lccccccc} 
& \multicolumn{7}{c}{ Accommodation } \\
& Parents & Hostel & Commune & Own & Other & No response & Total \\
\hline Afrikaans & 104 & 40 & 13 & 36 & 4 & - & 197 \\
English & 98 & 55 & 17 & 46 & 2 & - & 218 \\
Number & 202 & 95 & 30 & 82 & 6 & - & 415 \\
$\%$ & 48,7 & 22,9 & 7,2 & 19,8 & 1,4 & - & 100 \\
\hline
\end{tabular}

\begin{tabular}{|c|c|c|c|c|c|c|c|}
\hline & Parents & Bursary & $\begin{array}{c}\text { Fina } \\
\text { Loan }\end{array}$ & Self & Other & No response & Total \\
\hline Afrikaans & 133 & 10 & 39 & 9 & 5 & 1 & 197 \\
\hline English & 128 & 47 & 32 & 4 & 5 & 2 & 218 \\
\hline Number & 261 & 57 & 71 & 13 & 10 & 3 & 415 \\
\hline$\%$ & 63,3 & 13,8 & 17,2 & 3,2 & 2,5 & - & 100 \\
\hline
\end{tabular}

\section{Correlation between class attendance and academic performance}

During their second academic year, these students are introduced to the topic Consolidated and Separate Financial Statements (IAS 27) (IASB, 2006). They therefore have no prior education or experience of the topic which could influence their performance in the assessments. As such, this analysis was restricted to attendance and performance in this topic. This topic is presented in 22 lecturers over a period of seven weeks and is assessed by means of four written assessments.

To further control for the effect of prior exposure to the topic, when determining the impact of absenteeism on academic performance, only students who were enrolled for the module for the first time were included in the population for statistical analysis. Students with prior knowledge of the topic $(n=177)$ could score higher marks as they may be able to fall back on their existing knowledge and could have more experience in answering questions on 
the topic ${ }^{3}$. Students who were enrolled for the module for the first time and who missed one of the predetermined assessments $(n=18)$ were also excluded as they wrote a different supplementary test or examination, which may introduce an additional variable into the study. The final number of students included in the population for statistical analysis was 247 .

Actual attendance was determined with reference to attendance registers ${ }^{4}$. These attendance registers were administered by class representatives and verified by head counts performed by the representatives. The students were aware of these head counts and that a randomized sample of individual attendance records were verified by the lecturer in class. Further, the lecturers verified the total head count on a random basis. The students' marks obtained in the four written assessments were used as a proxy for academic performance. No marks were awarded for attendance and the students were made aware of this.

\section{Results and discussion}

\section{Attendance patterns and benefits}

The average attendance recorded for the module was $90 \%$, with the lowest average attendance recorded of $80 \%$ and the highest attendance recorded of $98 \%$. Paisey and Paisey (2004) reported an average attendance of $80 \%$. The difference in average attendance may be attributable to the fact that more of the Scottish students were required to work part-time to fund their studies than is the case in this study. Several studies in US have confirmed that part-time work has a negative effect on rates of college attendance (see for example Carr et al., 1996; McNeal, 1997; Warren et al., 2000). Despite this difference, the average attendance reported by Paisey and Paisey (2004) and in this study appears fairly high. This observation is not surprising as both modules formed part of a full-time degree course. In addition, accounting has an underlying mathematical nature and it has been suggested that absenteeism is generally lower in courses that have a significant mathematical component (Romer, 1993:168). Given the high attendance levels reported, it is unsurprising that the majority of the respondent students to this study either 'strongly agreed' $(62,2 \%)$ or 'agreed' $(27,4 \%)$ that regular attendance of the lectures would improve their academic performance (table III)

\footnotetext{
${ }^{3}$ Separate analysis of the attendance patterns of those students repeating the module is precluded by the fact that these students' attendance patterns are artificially reduced as they have timetable clashes with other courses from the next academic level.

${ }^{4}$ Attendance registers were not kept for other modules in the course. However, an unannounced lecturer evaluation (which are routinely conducted) completed, by the specific second year students under review, during their second year, but outside the study period, revealed a $90 \%$ attendance, providing some support for the reasonability of the attendance rates over the study period.
} 
Table III: "In your opinion do you believe that regularly attending lectures would improve a student's academic performance?"

\begin{tabular}{lcc}
\hline & Number & $\%$ \\
\hline Strongly agree & 257 & 62,2 \\
Agree & 113 & 27,4 \\
Slightly agree & 27 & 6,5 \\
Neither agree nor disagree & 12 & 2,9 \\
Slightly disagree & 0 & - \\
Disagree & 2 & 0,5 \\
Strongly disagree & 2 & 0,5 \\
No response & 2 & - \\
\hline Total & 415 & 100 \\
\hline
\end{tabular}

To elicit further detail as to what students' perceptions of the apparent benefits of class attendance were, the following open-ended question was posed to them:

"What do you believe are the main benefits of regular attendance of the lectures?"

The responses to this question are summarized in table IV. The vast majority of students expressed the view that class attendance would enhance their awareness of the relevant 'concepts' and improve their understandings thereof. Further, the students valued the opportunity for interaction in the classroom, the overall improvement in their study efficiency and the additional 'coaching' they would receive in exam-type questions.

Table IV: What do you believe are the main benefits of regular attendance of the lectures?

\begin{tabular}{|c|c|c|}
\hline \multirow[b]{2}{*}{ Response } & \multicolumn{2}{|c|}{$\begin{array}{r}\text { Frequency } \\
(n=415)\end{array}$} \\
\hline & $n$ & $\%$ \\
\hline \multicolumn{3}{|l|}{ To gain awareness and a greater understanding of the topic } \\
\hline $\begin{array}{l}\text { To gain a better understanding of the concepts and principles contained in the } \\
\text { material }\end{array}$ & 146 & 35,1 \\
\hline $\begin{array}{l}\text { Obtain clarity on the difficult sections; lecturers explain the complex topics in } \\
\text { class; work is explained }\end{array}$ & 58 & 14,0 \\
\hline $\begin{array}{l}\text { Additional explanations are provided and knowledge is gained that is not in the } \\
\text { textbook }\end{array}$ & 22 & 5,3 \\
\hline $\begin{array}{l}\text { Comprehension of the 'bigger picture' and the reason why consolidated financial } \\
\text { statements are compiled }\end{array}$ & 25 & 6,0 \\
\hline Lectures make students aware of the most important concepts & 21 & 5,1 \\
\hline \multicolumn{3}{|l|}{ To benefit from the interaction in class } \\
\hline $\begin{array}{l}\text { Opportunity to ask questions and learn from other students' questions, } \\
\text { interactions and discussions }\end{array}$ & 37 & 8,9 \\
\hline \multicolumn{3}{|l|}{ To improve overall study efficiency } \\
\hline Keeping up to date with the work & 23 & 5,5 \\
\hline Reduction of on own study time & 51 & 12,3 \\
\hline Obtain better marks & 2 & - \\
\hline \multicolumn{3}{|l|}{ To be 'coached' in answering of exam-type question } \\
\hline $\begin{array}{l}\text { Obtaining the lecturer's opinion on how to answer questions and guidance on } \\
\text { how questions might be asked }\end{array}$ & 12 & 2,9 \\
\hline Practical examples & 12 & 2,9 \\
\hline
\end{tabular}


Despite highlighting these benefits, when the students were asked, "what, if anything, could the department/lecturers do to help improve attendance in this module?", the most common response was "make it more interesting and give more practical examples" $(n=15)$. This response may be indicative of the 'boring' nature of the teacher-centred lectures in which the students are primarily passive recipients of information imparted upon them by the lecturer. The request for more 'practical' examples may be a further indication that students wish to be challenged by more real-life scenarios, rather than fictitious one correct answer exam type questions. However, it is submitted that it may alternatively be indicative of the students demanding additional 'coaching' for the professional qualifying examination. Other interventions suggested by the students to improve class attendance are:

- $\quad$ take in homework $(\mathrm{n}=7)$;

- introduce unannounced tests in class time $(n=7)$;

- give "tips" $(\mathrm{n}=4)$, and

- give bonus marks for attendance $(n=4)$.

Some students even cheekily commented that lecturers should give the students sweets in class to improve class attendance $(n=3)$.

\section{Reasons for non-attendance}

Despite the apparent support for class attendance some students continued to be absent from lectures to varying degrees. The main reason given by students for not attending lectures was illness $(n=60)$. The following reasons were also given for absence from lectures:

- timetable clashes (This is a valid reason for students who are repeating the second-year modules and who are registered for certain third-year modules) $(n=26)$;

- $\quad$ studying for another subject $(n=21)$;

- $\quad$ traffic or other transport problems $(n=24)$; or

- $\quad$ oversleeping $(n=6)$.

In contrast, Paisey and Paisey (2004) reported the following principle reasons for absence from lecturers:

- $\quad$ part-time work $(n=23)$;

- $\quad$ working on course work $(n=18)$;

- $\quad$ illness $(n=15)$;

- $\quad$ personal reasons (including hangover) $(n=4)$. 
Although there is some commonality in these findings (for example illness, working on course work or other subjects and personal reasons) there are some important differences. Part-time work was not a challenge for the current respondent group as their parents primarily fund their studies (table II). In contrast, many of the Scottish students were required to work part-time to fund their studies (Paisey \& Paisey, 2004). As anticipated, the lack of public transport in South Africa appears to be a challenge not experienced the Scottish students. Therefore, while there may be some generalizability in the reasons for non-attendance of accounting lectures, there may be reasons which are particular to a given country or economic environment.

\section{Correlation of attendance and performance}

Despite the students' perception that class attendance does improve academic performance, statistical evidence of this correlation was sought. A Pearson's Correlation Coefficient was calculated for the attendance prior to each assessment and the average mark obtained in that assessment. All assessment activities exhibited a positive correlation, which is significant on the $5 \%$ level, but the correlation coefficient is relatively low (table V). Furthermore, the strength of this correlation shows a declining trend from the first and second assessments $(r=$ 0,29 and 0,23 respectively) through to the third assessment and examination ( $r=0,18$ and 0,13 respectively). Class attendance prior to the first and second assessments may have a higher correlation with the marks, as these assessments primarily consider the new work dealt with immediately preceding each assessment. The third assessment and examination consider work dealt with over the entire duration of the topic. No new information is added following the second assessment. Further, these final assessments are administered sometime after completion of the topic and it is therefore possible that other intervening variables (such additional consultation with lecturers) may lesser the contribution of attendance in the performance of the students in these final assessments. Interestingly, the student who obtained the highest mark in the examination (88\%) had an overall attendance rate of $100 \%$ throughout the module. The student who obtained the lowest mark in the examination (8\%) had an overall attendance rate of $76 \%$ throughout the module. However the student who obtained the second lowest mark in the examination (14\%) had an attendance rate of $100 \%$. On average, students who failed the final assessment had a total attendance rate of $89 \%$, whilst students who passed the final assessment had a total attendance rate of $93 \%$. 
Table V: Pearson's Correlation Coefficient $(r)$ calculated for the marks and the attendance of the group in total

\begin{tabular}{lcccc} 
& \multicolumn{2}{c}{ Attendance } & Third assessment & Examination \\
Marks & First assessment & Second assessment & $r$ \\
\hline $\begin{array}{l}\text { First assessment } \\
\text { Second assessment }\end{array}$ & $r$ & $r$ & & \\
$\begin{array}{l}\text { Third assessment } \\
\text { Examination }\end{array}$ & $0.29^{*}$ & $0.23^{*}$ & $0.18^{*}$ & $0.13^{*}$ \\
\hline * Significant on the 5\% level. & & &
\end{tabular}

As the level of correlation at the individual level is reasonably low, the average attendance for the total group was subdivided into four categories, namely: attendance levels of $0 \%-79 \% ; 80 \%-89 \% ; 90-99 \%$; and $100 \%$ to determine whether a stronger correlation could be identified for a particular group of students. As a very high percentage of attendance for the group was achieved, it was not possible to subdivide the $0-79 \%$ group any further, as statistically insignificant $n$-values would have resulted from such a subdivision.

The Kruskal Wallis test was performed to compare the categories of attendance with the average mark obtained by students who fall within each of the 4 categories (table VI). Kruskal Wallis is a non-parametric technique, which is suitable for use in cases in which a normal distribution is not present. For the first, second and third assessment a significant difference was identified between the average marks obtained by the group of students who attended less than $79 \%$ of lectures and the group of students who attended $100 \%$ of the lectures. There was, however, no such significant difference in respect of the marks obtained in the examination.

Table VI: Kruskal Wallis Test: Average attendance and marks for the total group, split into category attendances

\begin{tabular}{|c|c|c|c|c|c|c|c|}
\hline \multicolumn{4}{|c|}{$\begin{array}{l}\text { First assessment } \\
\quad p=0.0044\end{array}$} & \multicolumn{4}{|c|}{$\begin{array}{l}\text { Second assessment } \\
p=0.0021\end{array}$} \\
\hline $\begin{array}{l}\text { Atten- } \\
\text { dance }\end{array}$ & $M$ & $S D$ & $\begin{array}{l}\text { Median } \\
\text { Mark }\end{array}$ & $\begin{array}{l}\text { Atten- } \\
\text { dance }\end{array}$ & $M$ & $S D$ & $\begin{array}{c}\text { Median } \\
\text { Mark }\end{array}$ \\
\hline $0-79$ & $75.5^{\mathrm{a}}$ & 16.3 & 75.0 & $0-79$ & $58.3^{\mathrm{a}}$ & 17.6 & 54.0 \\
\hline $80-89$ & $77.3^{\mathrm{ab}}$ & 14.3 & 77.0 & $80-89$ & $63.3^{\mathrm{ab}}$ & 19.7 & 66.5 \\
\hline $90-99$ & $81.1^{\mathrm{ab}}$ & 10.7 & 82.5 & $90-99 *$ & & & \\
\hline 100 & $84.3^{\mathrm{b}}$ & 11.5 & 87.5 & 100 & $68.0^{\mathrm{b}}$ & 15.3 & 68 \\
\hline
\end{tabular}




\begin{tabular}{|c|c|c|c|c|c|c|c|}
\hline \multicolumn{4}{|c|}{$\begin{array}{l}\text { Third assessment } \\
\quad p=0.0126\end{array}$} & \multicolumn{4}{|c|}{$\begin{array}{c}\text { Examination } \\
p=0.0287\end{array}$} \\
\hline $\begin{array}{l}\text { Atten- } \\
\text { dance }\end{array}$ & $M$ & $S D$ & $\begin{array}{l}\text { Median } \\
\text { Mark }\end{array}$ & $\begin{array}{l}\text { Atten- } \\
\text { dance }\end{array}$ & $M$ & $S D$ & $\begin{array}{c}\text { Median } \\
\text { Mark }\end{array}$ \\
\hline $0-79$ & $51.7^{\mathrm{a}}$ & 15.5 & 53.7 & $0-79$ & $45.7^{\mathrm{a}}$ & 15.2 & 47.2 \\
\hline $80-89$ & $55.2^{\mathrm{ab}}$ & 16.6 & 54.9 & $80-89$ & $51.8^{\mathrm{a}}$ & 11.8 & 52.8 \\
\hline $90-99$ & $57.8^{\mathrm{ab}}$ & 12.0 & 58.5 & $90-99$ & $49.0^{\mathrm{a}}$ & 11.9 & 49.1 \\
\hline 100 & $61.1^{\mathrm{b}}$ & 13.6 & 64.6 & 100 & $54.3^{\mathrm{a}}$ & 14.2 & 56.7 \\
\hline
\end{tabular}

Despite the overall high attendance rate for the module in this study, there were still students who did not perform well and even some who failed. The statistical analysis suggests only a slight positive correlation between attendance and performance.

\section{Correlation of attendance and performance by language group}

Given that the analysis of the student group as a whole and in categories based on academic performance revealed a low correlation, the analysis was repeated for the English- and Afrikaans groups. A Pearsons Correlation Coefficient for each assessment was calculated for each language group. The results are illustrated in tables VII and VIII. The Afrikaans group displays a slightly higher level of positive correlation than the English group, although still no more than a casual relationship between attendance and performance is found. In line with the findings of the group as a whole, the Afrikaans group exhibits a declining trend of positive correlation between the first assessment $(r=0.49)$ and the examination $(r=0,20)$ (see table VII). This trend is however not evident for the English students (see table VIII).

Table VII: Pearson's Correlation Coefficient $(r)$ calculated for the marks and the attendance of the Afrikaans group

\begin{tabular}{lcccc} 
& & \multicolumn{2}{c}{ Attendance } \\
Marks & First assessment & Second assessment & Third assessment & Examination \\
& $r$ & $r$ & & $r$ \\
\hline $\begin{array}{l}\text { First assessment } \\
\text { Second assessment } \\
\text { Third assessment }\end{array}$ & $0.49^{*}$ & $0.29^{*}$ & 0.11 & \\
Examination & & & & $0.20^{*}$ \\
\hline
\end{tabular}

* Significant on the $5 \%$ level. 
Table VIII: Pearson's Correlation Coefficient $(r)$ calculated for the marks and the attendance of the English group

\begin{tabular}{lcccc} 
& & \multicolumn{2}{c}{ Attendance } \\
Marks & First assessment & Second assessment & Third assessment & Examination \\
First assessment & 0.13 & $r$ & & $r$ \\
$\begin{array}{l}\text { Second assessment } \\
\text { Third assessment }\end{array}$ & & 0.16 & $0.25^{*}$ & \\
Examination & & & 0.07 \\
\hline$* \quad$ Significant on the 5\% level. & & & \\
\end{tabular}

A Kruskal Wallis test was performed for each of the language groups to compare the four categories of attendance with the average mark obtained by students that fall within each of the categories (table IX and table X).

Table IX: Kruskal Wallis Test: Average attendance and marks for the Afrikaans group, split into categories of attendance

\begin{tabular}{|c|c|c|c|c|c|c|c|}
\hline \multicolumn{4}{|c|}{$\begin{array}{c}\text { First assessment } \\
p=0.0000\end{array}$} & \multicolumn{4}{|c|}{$\begin{array}{l}\text { Second assessment } \\
\qquad p=0.0053\end{array}$} \\
\hline $\begin{array}{l}\text { Atten- } \\
\text { dance }\end{array}$ & $M$ & $S D$ & $\begin{array}{l}\text { Median } \\
\text { Mark }\end{array}$ & $\begin{array}{l}\text { Atten- } \\
\text { dance }\end{array}$ & $M$ & $S D^{3}$ & $\begin{array}{c}\text { Median } \\
\text { Mark }\end{array}$ \\
\hline $0-79$ & $66.8^{\mathrm{ab}}$ & 15.5 & 70.0 & $0-79$ & $55.8^{\mathrm{a}}$ & 18.5 & 52.0 \\
\hline $80-89$ & $70.4^{\mathrm{a} b}$ & 4.15 & 68.0 & $80-89$ & $57.2^{\mathrm{a} b}$ & 20.5 & 59.5 \\
\hline $90-99$ & $81.2^{a b c}$ & 11.6 & 83.0 & $90-99 *$ & & & \\
\hline 100 & $86.5^{\mathrm{c}}$ & 10.3 & 88.0 & 100 & $67.2^{\mathrm{b}}$ & 15.7 & 68.0 \\
\hline
\end{tabular}

Means with a different superscript differ significantly on the $5 \%$ level.

* - No students fell into this grouping for second assessment.

Table IX continues

\begin{tabular}{|c|c|c|c|c|c|c|c|}
\hline \multicolumn{4}{|c|}{$\begin{array}{c}\text { Third assessment } \\
p=0.6247\end{array}$} & \multicolumn{4}{|c|}{$\begin{array}{c}\text { Examination } \\
p=0.0434\end{array}$} \\
\hline $\begin{array}{l}\text { Atten- } \\
\text { dance }\end{array}$ & $M$ & $S D$ & $\begin{array}{c}\text { Median } \\
\text { Mark }\end{array}$ & $\begin{array}{l}\text { Atten- } \\
\text { dance }\end{array}$ & $M$ & $S D$ & $\begin{array}{c}\text { Median } \\
\text { Mark }\end{array}$ \\
\hline $0-79$ & $53.6^{\mathrm{a}}$ & 17.1 & 55.5 & $0-79$ & $39.2^{\mathrm{a}}$ & 14.3 & 42.0 \\
\hline $80-89$ & $54.5^{\mathrm{a}}$ & 19.9 & 56.1 & $80-89$ & $46.6^{\mathrm{a}}$ & 13.2 & 48.1 \\
\hline $90-99$ & $59.5^{\mathrm{a}}$ & 12.1 & 59.8 & $90-99$ & $51.8^{\mathrm{a}}$ & 11.9 & 50.5 \\
\hline 100 & $60.1^{\mathrm{a}}$ & 14.5 & 62.2 & 100 & $54.5^{\mathrm{a}}$ & 15.1 & 53.8 \\
\hline
\end{tabular}

Means with a different superscript differ significantly on the $5 \%$ level

In respect of the first assessment, significant differences were found between Afrikaans students who attended less than $79 \%$ of the lectures and students who attended $100 \%$ of the lectures as well as between students who attended $80-89 \%$ of the lectures and students who attended all the lectures (see table IX). In the second assessment, a significant difference was only found between students who attended $0-79 \%$ of the lectures and students who attended $100 \%$ of the lectures. No significant differences were found in respect of the third assessment or the examination (see table IX). This result may indicate that the influence of lectures on academic performance in the Afrikaans group decreases with the 
increasing length of the period between the presentation of these lectures and the assessment date.

Table X: Kruskal Wallis Test: Average attendance and marks for the English group, split into category attendances

\begin{tabular}{|c|c|c|c|c|c|c|c|}
\hline \multicolumn{4}{|c|}{$\begin{array}{c}\text { First assessment } \\
p=0.9799\end{array}$} & \multicolumn{4}{|c|}{$\begin{array}{l}\text { Second assessment } \\
p=0.2810\end{array}$} \\
\hline $\begin{array}{l}\text { Atten- } \\
\text { dance }\end{array}$ & $M$ & $S D$ & $\begin{array}{c}\text { Median } \\
\text { Mark }\end{array}$ & $\begin{array}{l}\text { Atten- } \\
\text { dance }\end{array}$ & $M$ & $S D$ & $\begin{array}{c}\text { Median } \\
\text { Mark }\end{array}$ \\
\hline $0-79$ & $79.2^{\mathrm{a}}$ & 15.3 & 81.0 & $0-79$ & $62.3^{\mathrm{a}}$ & 15.6 & 59.0 \\
\hline $80-89$ & $79.7^{\mathrm{a}}$ & 15.9 & 85.0 & $80-89$ & $66.3^{\mathrm{a}}$ & 18.9 & 70.0 \\
\hline $90-99$ & $81.0^{\mathrm{a}}$ & 10.1 & 80.0 & 90-99* & & & \\
\hline 100 & $81.3^{\mathrm{a}}$ & 12.3 & 82.5 & 100 & $68.7^{\mathrm{a}}$ & 14.9 & 70.0 \\
\hline
\end{tabular}

Means with a different superscript differ significantly on the $5 \%$ level.

* - No students fell into this grouping for second assessment.

Table $X$ continues

\begin{tabular}{|c|c|c|c|c|c|c|c|}
\hline \multicolumn{4}{|c|}{$\begin{array}{c}\text { Third assessment } \\
p=0.0341\end{array}$} & \multicolumn{4}{|c|}{$\begin{array}{l}\text { Examination } \\
p=0.0290\end{array}$} \\
\hline $\begin{array}{l}\text { Atten- } \\
\text { dance }\end{array}$ & $\bar{M}$ & $S D$ & $\begin{array}{c}\text { Median } \\
\text { Mark }\end{array}$ & $\begin{array}{l}\text { Atten- } \\
\text { dance }\end{array}$ & $\bar{M}$ & $S D$ & $\begin{array}{c}\text { Median } \\
\text { Mark }\end{array}$ \\
\hline $0-79$ & $50.2^{\mathrm{a}}$ & 14.5 & 47.6 & $0-79$ & $49.7^{\mathrm{ab}}$ & 14.8 & 52.8 \\
\hline $80-89$ & $55.7^{\mathrm{a}}$ & 13.9 & 54.9 & $80-89$ & $55.4^{\mathrm{ab}}$ & 9.5 & 53.8 \\
\hline $90-99$ & $56.7^{\mathrm{a}}$ & 11.9 & 57.3 & $90-99$ & $47.1^{\mathrm{a}}$ & 11.7 & 48.1 \\
\hline 100 & $62.5^{\mathrm{a}}$ & 12.1 & 64.6 & 100 & $54.1^{b}$ & 13.3 & 56.6 \\
\hline
\end{tabular}

Means with a different superscript differ significantly on the $5 \%$ level.

In contrast with the Afrikaans group, no significant difference was found for the English students in any assessment other than the examination. In the examination, there is an inexplicable, significant difference between the students who attended $90-99 \%$ of the lectures in comparison with the students who attended $100 \%$ of the lectures (see table X). However, the remainder of the results for the English group indicate that there is no significant difference between the marks of students, regardless of whether they attended all the lectures or less than $79 \%$ of the lectures.

Although further investigation will be required in future studies, the results based on the analysis by language group raises the question, given the dominance of White students in the Afrikaans group and African students in the English group, as to the effect of different ethnic and cultural environments on class attendance and the correlation with academic performance of students from different backgrounds.

\section{Conclusion}

Paisey and Paisey (2004) provided preliminary confirmation in an accounting education context, of the generalizability of theories developed in the broader field of business 
education literature of the reasons for non-attendance of lectures and the positive correlation between class attendance and academic performance in a small accounting class in Scotland. The objective of this study was therefore to determine the generalizability of these theories to a larger accounting class in South Africa. This study was a differentiated replication of the study of Paisey and Paisey (2004) to determine, in the context of larger accounting classes in South Africa, the reasons for non-attendance of class and to determine whether, or not, class attendance has a significant influence on academic performance.

The spectrum of reasons given by the respondents for non-attendance of lectures generally corresponds with those reported by Paisey and Paisey (2004). Certain differences as result of specific country or economic factors were however identified, limiting the generalizability of any theories developed on the reasons for non-attendance of accounting classes across international and economic boundaries.

Although this study found a significant positive correlation between class attendance and academic performance, the correlation was low and not very meaningful. These findings suggest that the large class environment, its situation in South Africa's cultural and economic environment or a combination of the two may reduce the effect of class attendance on academic performance. Further differentiated replication studies, isolating the effect of these variables in an accounting education context, may assist in clarifying the matter.

Given that literature outside an accounting context has previously confirmed a positive correlation between class attendance and academic performance in larger classes (see for example Romer, 1993; Gump, 2005; Halpern, 2007) the nature of accounting pedagogy in South African accounting education may need to be questioned. Perhaps the students' request to "make it more interesting and give more practical examples' needs to be taken seriously by accounting educators. The current teacher-centred teaching environment, relying on fictitious single answer textbook scenarios, may need to be reconsidered. Accounting education literature provides a wealth of alternative student orientated approaches which may be 'more interesting'.

Given the low correlation for the group as a whole the analysis was repeated by language group. Some differences between the English- and Afrikaans students were identified. These findings raise questions as to the possible effects of culture and ethnicity difference in the benefits of class attendance. Differing learning styles between cultural and ethnicity groups may therefore provide interesting avenues of exploration for future studies into the effects of non-attendance of lectures and academic performance - particularly in nonwestern cultural environments. Further investigation into cultural and ethnic differences 
between the lecturer and the students may also present interesting opportunities for future research

Finally, this study made no attempt at determining a causal relationship between class attendance and academic performance, instead focusing on any possible correlation between these two variables. Identifying such a relationship in an accounting education context may provide further opportunity for future investigation. Despite the fact that only a weak correlation was identified and no attempt was made to identify a causal relationship, the students' perception that the attendance of lectures increases performance should not be underestimated:

“You know you will pass if you attend!" (Respondent student)

\section{References}

Botha, W.J.J. (2001), "Pre-qualification education of registered accountants and auditors in South Africa: perspectives on whether the education process is normatively justifiable", Meditari: Research Journal of the School of Accounting Sciences Vol. 9, pp. 33-59.

Booth, P., and Winzar, H. (1993), "Personality biases of accounting students: Some implications for learning style preferences", Accounting \& Finance, Vol. 33 No. 2, pp. 109-120.

Briggs, S. P., S. Copeland, and D. Haynes. (2007), "Accountants for the 21st Century, where are you? A fiveyear study of accounting students' personality preferences", Critical Perspectives in Accounting, Vol. 18 No. 5, pp. 511-537.

Carr, R.V., Wright, J. D., \& Brody, C. J. (1996). Effects of high schoolwork experience a decade later: Evidence from the National Longitudinal Survey. Sociology of Education, Vol 69, pp. 66-81.

Chen, J. \& Lin, T. (2008), "Class Attendance and Exam Performance: A Randomized Experiment”, The Journal of Economic Education, Vol. 39 No. 3, pp. 213-227.

Credé, M., Roch, S.G.\& Kieszczynka, U.M. (2010), “Class Attendance in College”, Review of Educational Research, Vol. 80 No. 2, pp. 272-295.

de Swaan, A, (2001), "Words of the world: the global language system". Wiley-Blackwell.

Devadoss, S. \& Foltz, J. (1996), "Evaluation of Factors Influencing Student Class Attendance and Performance", American Journal of Agriculture Economics, Vol. 78 No.3, pp. 499-507.

Durden, G.C. \& Ellis, L.V. (1995), "The Effects of Attendance on Student Learning in Principles of Economics", American Economic Review, Vol. 85 No. 2, pp. 343-346.

Gendron, P. \& Pieper, P. (2005), “Does Attendance Matter? Evidence from Ontario ITAL”, Unpublished draft for discussion.

Giacomino, D. E., and Akers, M.D. (1998), "An examination of the differences between personal values and value types of female and male accounting and nonaccounting majors". Issues in Accounting Education Vol. 13 No 3 pp. 565- 584.

Gump, S.E. (2005), "The Cost of Cutting Class: Attendance as a Predictor of Success". College Teaching, Vol. 53 No. 1, pp. 21-26.

Halpern, N. (2007), "The Impact of Attendance and Student Characteristics on Academic Achievement: Findings from an Undergraduate Business Management Module", Journal of Further \& Higher Education, Vol. 31 No. 4, pp. 335-349.

Horn, P.M. \& Jansen A.I. (2009), “Tutorial classes - Why Bother? An Investigation into the Impact of Tutorials on the Performance of Economics Students", South African Journal of Economics. Vol. 77 No. 1, pp. 179 -189. 
International Accounting Standards Board [IASB], (2006), IAS 27 - Consolidated and Separate Financial Statements. London: IASCF Publications Department.

Lindsay, R.M. \& Ehrenberg, A.S.C. (1993), “The Design of Replicated Studies” The American Statistician, Vol. 47 No. 3, pp. 217-228.

Longhurst, R.J. (1999), "Why aren't they here? Student absenteeism in a further education college", Journal of Further \& Higher Education, Vol. 23 No. 1, pp. 61-80.

Marburger, D.R. (2001), “Absenteeism and Undergraduate Exam Performance”, Journal of Economic Education, Vol. 32 No. 2, pp. 99-109.

Massingham, P. \& Herrington, T. (2006), "Does attendance matter? An examination of student attitudes, participation, performance and attendance", Journal of University Teaching and Learning Practice, Vol. 3 No. 2, pp. 82-103.

McChlery, S. \& Visser, S. (2009), “A comparative analysis of the learning styles of accounting students in the United Kingdom and South Africa", Research in Post-Compulsory Education, Vol. 14 No. 3, pp. 299-315.

McNeal, R. B. (1997). Are students being pulled out of high school? The effect of adolescent employment on dropping out. Sociology of Education, Vol 70, pp. 206-220.

Moore, S. \& Armstrong, C \& Pearson, J. (2008), "Lecture absenteeism among students in higher education: a valuable route to understanding student motivation", Journal of Higher Education Policy and Management, Vol. 30 No. 1, pp. 15-24.

Newman-Ford, L., Fitzgibbon, K., Lloyd, S. and Thomas, S. (2008), “A large-scale investigation into the relationship between attendance and attainment: a study using an innovative, electronic attendance monitoring system", Studies in Higher Education, Vol. 33 No. 6, pp. 699-717.

Paisey, C. \& Paisey, N.J. (2004), "Student attendance in an accounting module - reasons for non-attendance and the effect on academic achievement at a Scottish university", Accounting Education, Vol. 13 No. 1, pp. $39-53$.

Ridener, L. R. (1999). "Effect of college major on ecological worldviews: A comparison of business, science, and other students". Journal of Education for Business (September/October) pp. 15-21.

Rodgers, J. (2001), “A Panel-Data Study of the Effect of Student Attendance on University Performance”, Australian Journal of Education, Vol. 45 No. 3, pp. 284-295.

Rodgers, J.R. \& Rodgers, J.L. (2003), “An Investigation into the Academic Effectiveness of Class Attendance in an Intermediate Microeconomic Theory Class", Faculty of Commerce - Papers, 1-22. Available at: http://0ro.uow.edu.au.innopac.up.ac.za/cgi/viewcontent.cgi?article $=1175 \&$ context $=$ commpapers $($ accessed 25/07/2008).

Romer, D. (1993), “Do Students Go to Class? Should They?”, Journal of Economic Perspectives, Vol. 7 No. 3 , pp. 167-174.

Sauers, D.A. \& McVay, G.J. \& Deppa, B.D. (2005), “Absenteeism and academic performance in an introduction to business course”, Academy of Educational Leadership Journal, Vol. 9 No. 2, pp. 19-27.

Sleigh, M.J. \& Ritzer, D.R. (2001), "Encouraging student attendance”, Available at: http://www.psychologicalscience.org/observer/1101/tips.html (accessed 13/07/2008).

South African Institute of Chartered Accountants [SAICA]. (2005), Education requirements for entry into part 1 of the qualifying examination. Available at: http://www.saica.co.za. (accessed 01/12/2007).

St. Clair, K.L. (1999). A case against compulsory class attendance policies in higher education. Innovative Higher Education, Vol. 23 No .2, pp. 171-180.

Sugahara, S. \& Boland, G. (2010). "The Role of Cultural Factors in the Learning Style Preferences of Accounting Students: A Comparative Study between Japan and Australia", Accounting Education: An International Journal, Vol. 19 No. 3, pp. 235-255.

University of Pretoria [UP]. (2009), Learner's guide: Financial Accounting 201. UP Printers.

Van der Schyf, D.B. (2008), "The essence of a university and scholarly activity in accounting, with reference to a Department of Accounting at a South African university", Meditari: Research Journal of the School of Accounting Sciences, Vol. 16 No. 1, pp. 1-26. 
Warren, J. R., LePore, P. C., \& Mare, R. D. (2000). Employment during high school: Consequences for students' grades in academic courses. American Educational Research Journal, Vol. 37, 943-969.

Wolk, C., and Nikolai, L.A. (1997) "Personality types of accounting students and faculty: Comparisons and Implications", Journal of Accounting Education, Vol. 15 No.1, pp. 1-17.

Woodfield, R., Jessop, D. \& McMillan, L. (2006), "Gender differences in undergraduate attendance rates", Studies in Higher Education, Vol. 31 No. 1, pp. 1-22.

Ylijoki, O. (2000), "Disciplinary cultures and the moral order of studying - a case of four Finnish university departments". Higher Education, Vol. 39 No. 3, pp. 339-362. 